\title{
Denture Disinfection by Microwave at Different \\ Times and Powers
}

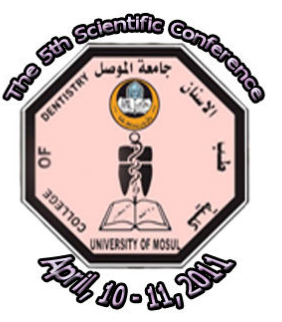

\begin{abstract}
Aims: To evaluate the best microwave power and the proper time that disinfect acrylic resin denture base material. Methodology: Fifty five samples were prepared from heat cured acrylic resin $(10 \mathrm{~mm} \times 10 \mathrm{mmx} 2 \mathrm{~mm})$ then immersed in glass flask containing brain heart broth and inculated with swabs from patients wearing complete denture divided into: negative control group (untreated), positive control group immersed in $0.02 \%$ sodium hypochlorite for 8 hours, and nine groups of different microwave disinfection settings (different powers and times), then immersed in sterile BHI broth individually and diluted up to $10^{-4}$ and $0.01 \mathrm{ml}$ plated in blood agar and Sabouraud's dextrose agar and $\mathrm{CFU} / \mathrm{ml}$ were collected. Results: analysis of the data showed a significant difference between tested groups. Conclusions: microwave disinfection at $900 \mathrm{~W}$ and $540 \mathrm{~W}$ for 3 minutes showed both antifungal and antibacterial effect.

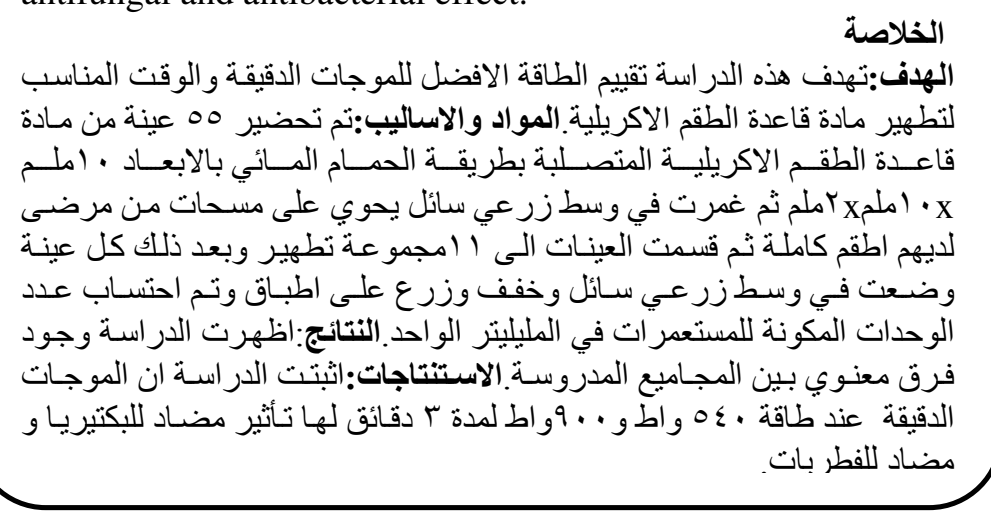

Asst.Lect.Alaa' N. Al-Saraj (BDS, M.Sc.); Asst Prof Munther N. Kazanji (BDS, MSc); Asst Prof Ghada Y. Abdul-Rahman (BDS, $M S c, P h D)$

Department of Prosthodontic Dentistry, Department of Basic Science, Dentistry College, Mosul University

Key Words: disinfection, microwave, denture base.

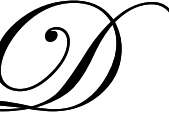

ental plaque is bacterial aggregation that are attached to the teeth or other solid oral structures ${ }^{(1)}$.

Formation of denture plaque by the normal oral flora is facilitated by the presence of debris due to poor hygiene, irregularities in the acrylic resin, the response of acrylic resin to a temperature of approximately $37^{\circ} \mathrm{C}$, and the negative pressure in the acrylic resin-mucosa interface $^{(2)}$.

Dental prostheses used by patients are exposed to the normal oral microbial flora which include bacteria, viruses and fungi. Dental personnel adjusting or repairing these prostheses may therefore be at risk of contracting infections from prostheses that have not been properly disinfected $^{(3)}$. 
Improved sterile techniques in handling patients' dental prostheses can substantially reduce cross contamination that may occur from the pumice and rag wheel. Thereby diminishing the patient's exposure to potentially pathogenic bacteria ${ }^{(4)}$.

Soaking denture of patients with denture stomatitis in $0.2 \%$ chlorhexidine overnight during five months led to no fungal growth either on palatal or on maxillary denture agar models, and clinical signs and symptoms were reduced ${ }^{(5)}$.

Chassot et al., ${ }^{(6)}$ concluded that immersion for at least 5 minutes in a $0.2 \%$ peracetic acidbased disinfectant promoted high level disinfection of heat polymerized, chemically activated and microwave-polymerized acrylic resins contaminated with either human saliva or Bacillus subtilis or Bacillus stearothermophilus.

Webb et al., ${ }^{(7)}$ demonstrated that the microwave irradiation of dentures at a specified setting and exposure time is bactericidal and fungicidal.

Webb et al., ${ }^{(8)}$ studied in vivo the efficacy of two methods of denture sterilization: microwave irradiation (350W for 6 minutes ) and sodium hypochlorite soak $(0.02 \%$ and $0.0125 \%$ for eight hours) against Candida albicans and Sterptcoccus gordonii. The result indicated that the microwaving may be a more effective method of denture sterilization than denture soaking in sodium hypochlorite. However, compared with microwaving, hypochlorite reduces the levels of residual non viable microorganisms attached to the denture surface.

\section{MATERIALS AND METHODS}

Fifty five samples were prepared from heat cured acrylic resin (Major base 2/ Major Prodotti Dentari / Italy) in dimensions of $1 \mathrm{~cm}$ width and length and $2 \mathrm{~mm}$ thickness for microbiological test. Then, the samples were sterilized by autoclave at 15 pound/ inch ${ }^{2} 121{ }^{\circ} \mathrm{C}$ for 15 minutes. $(8,9)$

The samples were divided into 11 groups :The first group is negative control (untreated), the second group positive control immersed in $0.02 \%$ sodium hypochlorite for 8 hours and nine groups of different microwave disinfection settings (different powers and times) include the following:

1. $900 \mathrm{~W}$ for 1,3 and 6 minuets which named $900 \mathrm{~W} 1,900 \mathrm{~W} 3$ and $900 \mathrm{~W} 6$ respectively.

2. $540 \mathrm{~W}$ for 1,3 and 6 minuets which named 540W1,540W3 and 540W6 respectively.

3. $180 \mathrm{~W}$ for 1,3 and 6 minuets which named 180w1,180W3 and 180W6 respectively.

\section{Sample Collection:}

Five patients forty to sixty years old wearing complete denture for at least 1 year with normal oral mucosa and no systemic diseases were randomly selected from Department of Prosthodontics, College of Dentistry, University of Mosul. Two plaque samples were collected from each patient, with sterile cotton swabs, one sample from the denture bearing area of the palate(swab is taken from incisive papilla along middle palatine line) and one from the corresponding fitting surface of the denture. This was done immediately after the removal of the denture $^{(10)}$ in addition to saliva sample was collected in sterile glass flask.

Each one of the collected samples were placed in a tube of sterile brain heart infusion broth(Oxoid). Then, the inoculated brain heart broth was put together in glass flask which containing the sterile acrylic resin specimens that prepared previously, and incubated at $37^{\circ} \mathrm{C}$ for 48 hours.

The acrylic samples was distributed as mentioned previously ,then each sample put in glass flask containing $4.5 \mathrm{ml}$ of sterile brain heart infusion broth and diluted up to $10^{-4}$ then $0.1 \mathrm{ml}$ of each final dilutions were plated on three Sabouraud 's Dextrose agar plates (Himedia) and three 
blood agar plates(Himedia) ${ }^{(10)}$, then incubated aerobically over night(18-24 hours) and the total counts of the colony forming unit per milliliter $(\mathrm{CFU} / \mathrm{ml})$ were done ${ }^{(11)}$.Figure $(1,2)$.

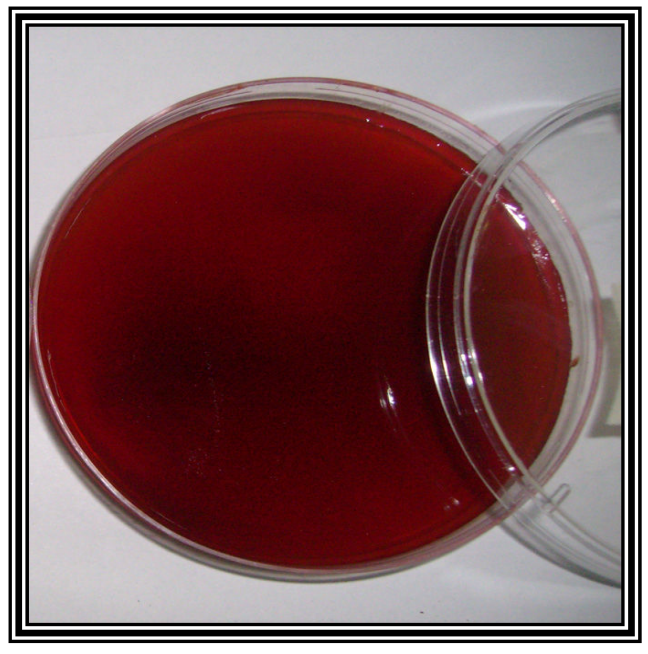

A

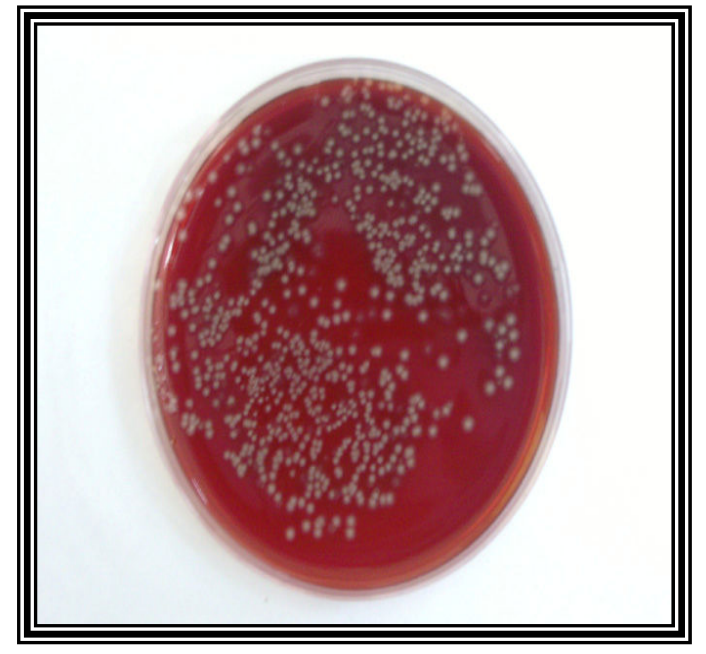

B

Figure(1): A: Blood Agar Petri dish for microwave disinfected samples; B: Blood agar Petri dish for control samples.

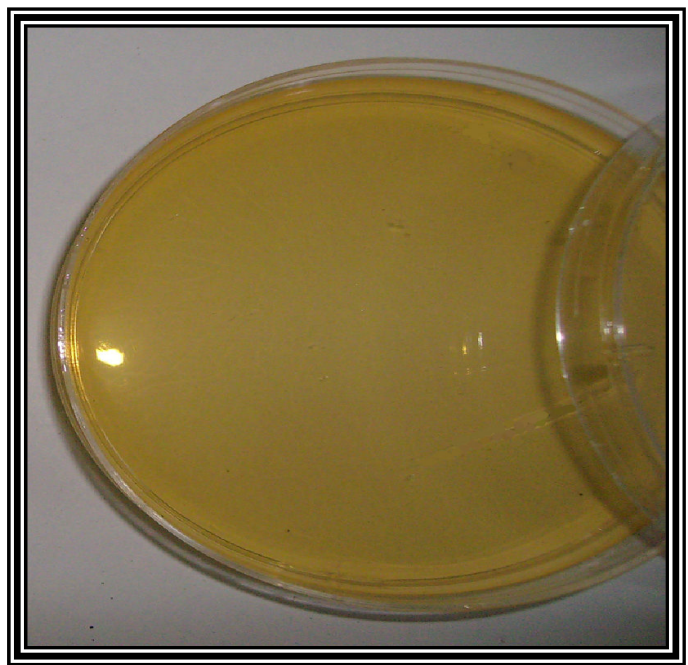

A

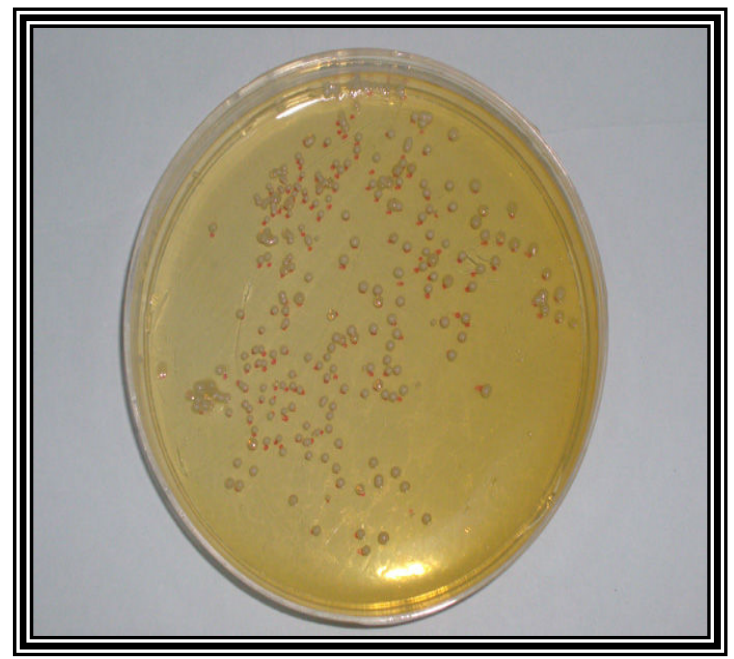

B

Figure(2): A: Sabouraud's dextrose agar Petri dish for microwave disinfected samples; B: Sabouraud's dextrose agar Petri dish for the control group.

\section{RESULLTS}

The collected data were submitted to the Kruskal-Wallis analysis of variance which showed significant difference between different groups at $\mathrm{P} \leq 0.05$ for both antifungal and antibacterial 
effect as in Tables $(1,2)$.

Table (1): Kruskal-wallis test for antibacterial effect of sodium hypochlorite and different microwave settings for Heat Cured Acrylic Resin Samples.

\begin{tabular}{|c|c|c|c|}
\hline Source of difference & Degree of freedom & Chi-square & $P$-value \\
\hline $\begin{array}{c}\text { Different disinfection } \\
\text { procedures }\end{array}$ & 10 & 97.146 & 0.000 \\
\hline
\end{tabular}

Table (2): Kruskal-wallis test for antifungal effect of sodium hypochlorite and different microwave settings of heat cured acrylic resin samples.

\begin{tabular}{|l|l|l|l|}
\hline Source of difference & Degree of freedom & Chi-square & $P$-value \\
\hline Different disinfection procedure & 10 & 45.169 & 0.000 \\
\hline
\end{tabular}

Dunn's multiple comparison test revealed the following :the antifungal effect showed a significant differences between control group and microwave disinfected groups with no significant difference between groups except $180 \mathrm{~W}$ for 1 minutes which showed the highest mean rank of CFU/ml (98).

The antibacterial effect revealed significant differences in mean rank of CFU/ml different microwave disinfection settings and in relation to control and significant difference between different groups with lowest mean rank of CFU/ml for $900 \mathrm{~W}$ for $3 \mathrm{~min}$ and $6 \mathrm{~min}$ and $540 \mathrm{~W}$ for $3 \mathrm{~min}$ and $6 \mathrm{~min}(64)$ and highest value is for $900 \mathrm{~W}$ and $540 \mathrm{~W}$ for $1 \mathrm{~min}(98.8) \mathrm{Table}(3)$, and Figures $(3,4)$.

Table (3): Dunn's multiple comparison test for antifungal and antibacterial effect by sodium hypochlorite and different microwave disinfection settings for heat cured acrylic resin.

\begin{tabular}{|c|c|c|c|c|c|}
\hline $\begin{array}{c}\text { Disinfection } \\
\text { settings }\end{array}$ & $\begin{array}{c}\text { Number of } \\
\text { observation }\end{array}$ & $\begin{array}{c}\text { Mean Rank } \\
\text { of CFU/ml } \\
\text { for } \\
\text { antifungal }\end{array}$ & $\begin{array}{c}\text { Multiple } \\
\text { Comparison } \\
\text { Grouping* }\end{array}$ & $\begin{array}{c}\text { Mean Rank } \\
\text { of CFU/ml } \\
\text { for } \\
\text { Antibacterial }\end{array}$ & $\begin{array}{c}\text { Multiple } \\
\text { Comparison } \\
\text { Grouping* }\end{array}$ \\
\hline 900w,1min & 15 & 73 & $\mathrm{C}$ & 84.27 & BC \\
\hline $540 \mathrm{~W}, 1 \mathrm{~min}$ & 15 & 73 & $\mathrm{C}$ & 98.9 & $\mathrm{~B}$ \\
\hline $180 \mathrm{~W}, 1 \mathrm{~min}$ & 15 & 98 & $\mathrm{~B}$ & 98.9 & $\mathrm{~B}$ \\
\hline $900 \mathrm{~W}, 3 \mathrm{~min}$ & 15 & 73 & $\mathrm{C}$ & 64 & $\mathrm{D}$ \\
\hline $540 \mathrm{~W}, 3 \mathrm{~min}$ & 15 & 73 & $\mathrm{C}$ & 64 & $\mathrm{D}$ \\
\hline $180 \mathrm{~W}, 3 \mathrm{~min}$ & 15 & 73 & $\mathrm{C}$ & 74 & $\mathrm{CD}$ \\
\hline $900 \mathrm{~W}, 6 \mathrm{~min}$ & 15 & 73 & $\mathrm{C}$ & 64 & $\mathrm{D}$ \\
\hline $540 \mathrm{~W}, 6 \mathrm{~min}$ & 15 & 73 & $\mathrm{C}$ & 64 & $\mathrm{D}$ \\
\hline $180 \mathrm{~W}, 6 \mathrm{~min}$ & 15 & 73 & $\mathrm{C}$ & 78 & $\mathrm{C}$ \\
\hline NaOCL & 15 & 73 & $\mathrm{C}$ & 64 & $\mathrm{D}$ \\
\hline Control & 15 & 158 & $\mathrm{~A}$ & 158 & $\mathrm{~A}$ \\
\hline
\end{tabular}

min: minutes ; W:watt

*Mean with different letters are statistically significant. 


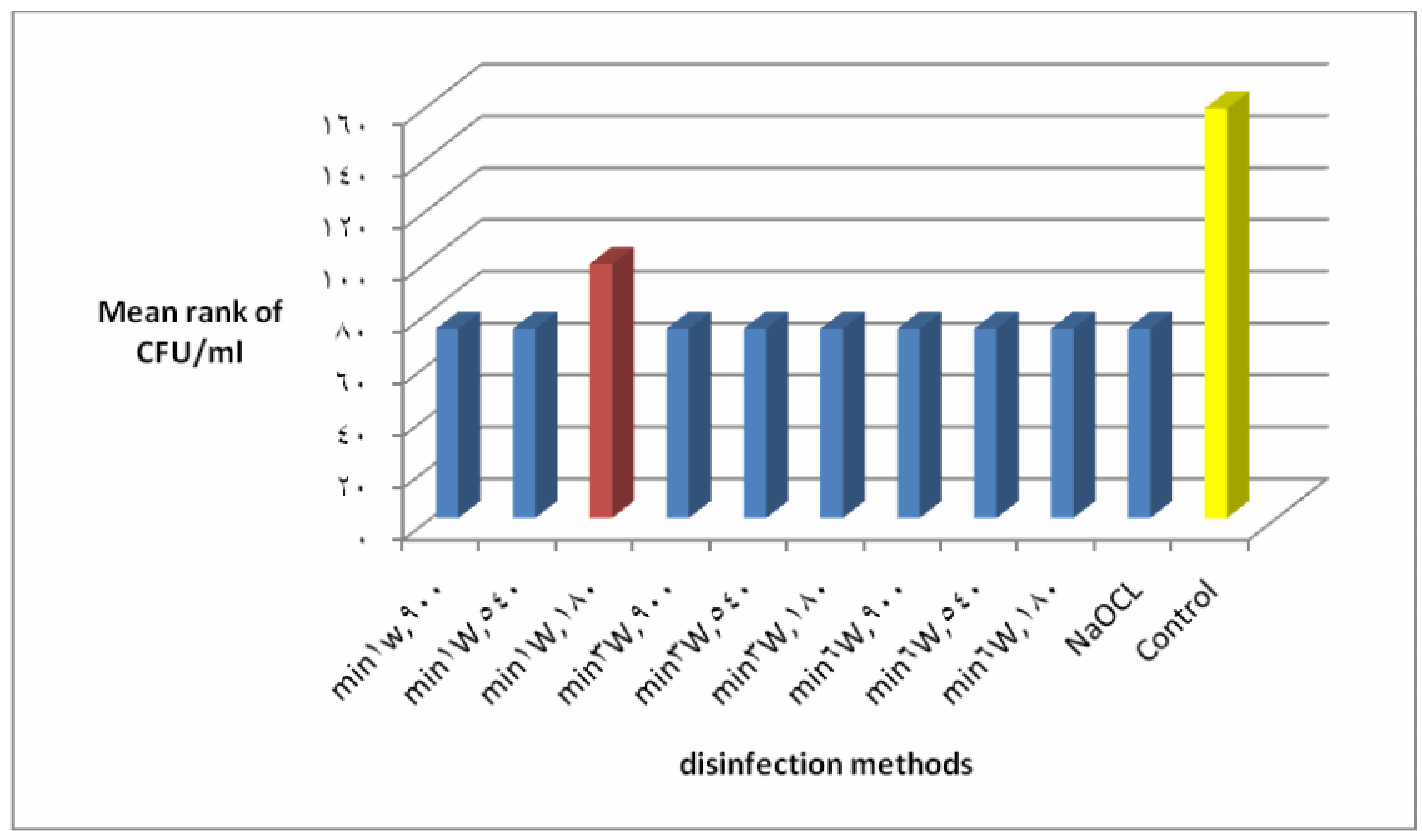

Figure (3): Mean rank of cfu/ml of antifungal effect of different microwave settings for heat cured denture base acrylic resin samples.

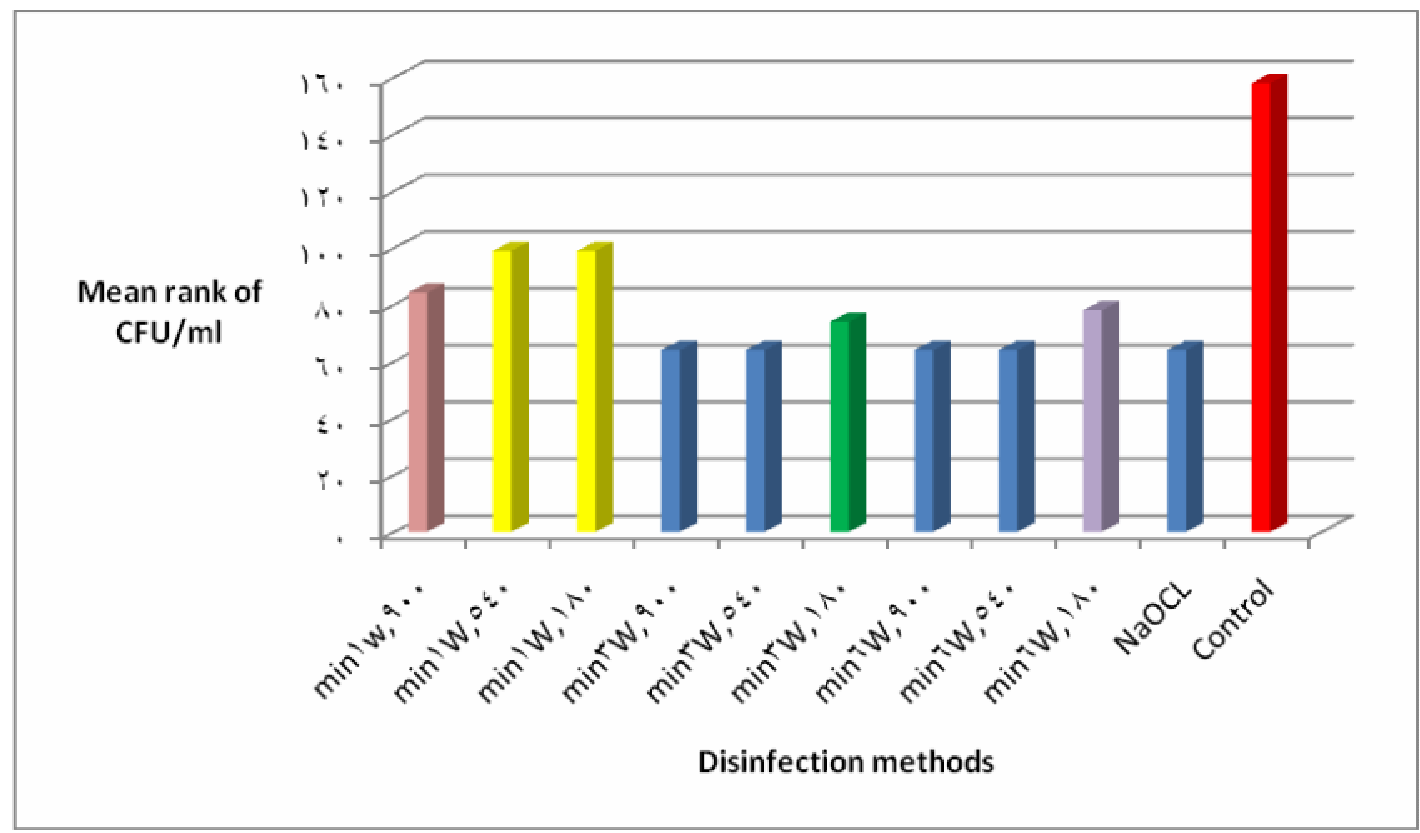

Journal of the $5^{\text {th }}$ Scientific Conference of Dentistry College, Apr. 2011 
Figure (4): Mean rank of cfu/ml of antibacterial effect of different microwave settings for heat cured denture base acrylic resin samples.

\section{DISCUSSION}

The result may be attributed to the change in structural integrity and permeability of cell membrane and cell wall and may have detrimentally affected the cell metabolism that lead to cell death or cause leakage of nucleic acid and protein from cell and as the nucleic acid is responsible for the genetic propagation, the loss of this molecule may have accounted for the lack of growth of the cells ${ }^{(12,13)}$.

Microwave disinfection may be owing to heating of the water in the cytoplasm of the bacteria which presumed to kill organism or render it incapable of cell division ${ }^{(14)}$.

The possible explanation for such result may be due to the alteration in cell morphology ${ }^{(8)}$. This induced by progressive series of alterations which were proportional to exposure time with the final stage being complete destruction of bacterial cell ${ }^{(15)}$.

Moreover, microorganisms generally contain high intracellular concentrations of ionizable compounds, which may absorb microwave thermal heat at a much greater rate than a surrounding liquid medium such as distilled water ${ }^{(16)}$.

\section{CONCLUSIONS}

Microwave disinfection at $900 \mathrm{~W}$ for $3 \mathrm{~min}, 900 \mathrm{~W}$ for $6 \mathrm{~min}, 540 \mathrm{~W}$ for $3 \mathrm{~min}$ and $540 \mathrm{~W}$ for $6 \mathrm{~min}$ were the best as antibacterial and anti fungal, since there is no significance between these four settings so microwave irradiation at $540 \mathrm{~W}$ for 3 min may be a potential treatment to prevent cross-contamination

\section{REFERENCES}

1. Nisengard R, Newman M. Oral microbiology and immunology . $2^{\text {nd }}$ ed. W.B. Saunders Company. (1994). Pp:347-348.

2. Catalan A, Herrera R, Martinez A. Denture plaque and palatal mucosa in denture stomatitis :Scanning electron microscopic and microbiologic study. J Prosthet Dent . (1987); 57(5):581-586.

3. Lin J, Cameron S, Runyan D, Craft D . Microwave disinfection of denture base acrylic resins. J Prosthet Dent.(1999);81:202-6.

4. Kahn RC, Lancaster MV, Kate W. The microbiologic cross-contaminutesation of dental prostheses. $J$ Prosthet Dent. (1982);47(5): 556-559.

5. Olsen I. Denture stomatitis. Relapse tendency and removal of acquired discolourations in long-term denture disinfection with chlorhexidine. Acta Odont. Scand. (1975); 33: 111-114.

6. Chassot A, Poisl M, Samuel S. In vivo and in vitro evaluation of the efficacy of a peracetic acid-based disinfectant for decontamination of acrylic resins. Braz Dent J. (2006); 17(2): 117-121.

7. Webb B, Thomas CJ, Whittle T. A 2-year study of Candida-associated denture stomatitis treatment in aged care subjects. Gerodontology. (2005);22:168-176.

8. Webb B, Thomas C, Harty D, Willcox M. Effectivness of two methods of denture sterilization. J Oral Rehabil. (1998);25:416-423.

9. Harrison Z, Johnson A, Douglas CW . An in vitro study into the effect of a limited range of denture cleaners on surface roughness and removal of Candida albicans from conventional heat-cured acrylic resin denture base material. J Oral Rehabil. (2004);31:460-467.

10. Koopmans A, Kippuw N, Graaff J. Bacterial Involvement in Denture-induced Stomatitis . J Dent Res. (1988); 67(9):1246-1250. 
11. Cruckshak R, Duguid TP, Marmion BP, Swain RHA. Medical microbiology. Vol.II. 12 $2^{\text {th }}$ ed Churchil, Livingestone. England. (1975); Pp: 301-310,154.

12. Woo I, Rhee I, Dong H. Differential damage in bacterial cells by microwave radiation on the basis of cell wall structure. Appl.Environ.Microbiol. (2000); 66(5):2243-2247.

13. Campanha NH, Pavarina AC, Brunetti IL, Vergani CA, Machado AL, Spolidorio DAP. Candida albicans inactivation and cell membrane integrity damage by microwave irradiation. J Compilation. (2007);50:140-147.

14. Culkin K, Fung D . Destruction of Escherichia coli and Salmonell tryphimurium in microwave cooked soups. $J$ Milk Food Technol;38:8-15. Cited by Dunsmiur R, Gallacher G (2003) microwave sterilization of femoral head allograft. J clin Microbiol. (1975);41(10):4755-4757.

15. Rosaspina S, Anzanel D, Salvatorelli G. microwave sterilization of enterobacteria. Microbios;76:263. Cited by Webb B, Thomas C, Harty D, Willcox M (1998) Effectivness of two methods of denture sterilization. J Oral Rehabil. (1993); 25:416-423.

16. Yeo C, Watson I, Tull D, Koh V. Heat transfer analysis of Staphylococcus aureus on stainless steel with microwave radiation. J Appl Microbiol. (1999); 87: 396-401. 